\title{
On Lesbian Acts and Female Pleasures in Juvenal Commentaries from Antiquity to 1500
}

\author{
MARC D. SCHACHTER \\ Durham University
}

\begin{abstract}
This article explores the representation of sex between women in an understudied archive: commentaries on Juvenal's Satires from antiquity to the end of the fifteenth century. By tracking the changes in glosses to a passage in the Sixth Satire that refers to sex between women, it contributes to our understanding of how and when the discourse on sex between women changed with the rise of humanism and the increased availability of classical texts after the advent of print in Europe. The article also addresses the vexed question of "lesbian" sex and female pleasure as understood in early modernity by considering the interpretations offered for Juvenal's mention of urinating women and their urine-which was sometimes taken to be female sperm generated through sexual contact between women. The article tracks how the implications of this generation are addressed in different commentaries to either emphasize or downplay female pleasure.
\end{abstract}

Cet article explore la représentation des pratiques sexuelles entre femmes dans les sources insuffisamment étudiées que sont les commentaires des Satires de Juvénal, de l'Antiquité à la fin du quinzième siècle. L'examen de lévolution des gloses à un passage de la sixième satire évoquant des rapports sexuels entre femmes permet de mieux comprendre quand et comment les discours à ce sujet se sont transformés, en rapport avec l'émergence de l'humanisme et la disponibilité croissante de textes de l'Antiquité classique avant l'arrivée de l'imprimerie en Europe. Cet article traite également de la question polémique de la sexualité «lesbienne » et du plaisir féminin, tel qu’ils étaient conçus pendant les débuts de la modernité, en examinant les interprétations de la mention que fait Juvénal de femmes urinant et de leur urine, cette dernière étant parfois considérée comme la semence féminine produite pendant le contact sexuel entre femmes. On retrace comment les conséquences de cette production sont traitées dans les différents commentaires qui accentuent ou minimisent le plaisir féminin.

$\mathrm{T}$ his exploratory essay tracks transformations in the representation of sex between women from late antiquity to the Renaissance in an underexplored archive. While scholars have addressed passages dealing with sex between women in works such as Juvenal's Sixth Satire (ca. 100 CE) and Martial's Epigrams (86-103 CE), they have not considered subsequent commentaries on them. In general, such commentaries offer insight into how figures belonging to now-distant presents tried to make sense of-or make use of-elements from 
yet-more-distant pasts. Historical glosses on passages potentially referring to sex acts between women can thus provide access to evolving understandingsamong men-of those acts. For instance, Juvenal commentaries suggest that representations of sex between women changed radically in the 1470s. It is at this point that the classical figure of the tribade first appears in glosses on the Satires, anticipating its circulation in the sixteenth-century medical texts so carefully studied by Katherine Park and Valerie Traub. (The word "tribade" was derived from the Greek verb tribô, "to rub," because of the sex act most commonly associated with "lesbian" sex in antiquity, namely rubbing the clitoris on or in the genitalia of another woman. $)^{1}$ Also of note in the commentaries from the 1470s are explicit discussions of lesbian oral sex that recent scholarship would not lead us to expect. My primary focus in the pages that follow however will be a series of references to the sperm generated by women during sexual relations with other women.

Whether women produced sperm was a topic hotly debated in pre-modernity. Followers of Aristotelian embryology often argued that women did not, and considered female sexual secretions to be forms of menstruation. According to Galenic tradition, on the other hand, sexual pleasure did indeed lead women to produce sperm, which many authors deemed necessary for reproduction. By the late Middle Ages and into the fifteenth century, medical writers "opted

1. I should make the standard disclaimer that I am not using the adjective "lesbian" as if it were a transhistorical identity category but rather to indicate that I am referring to sex acts between women. Nonetheless, against the claim that its use in this context is anachronistic, I would point out that some of the humanist commentators I will address below actually did think that there were "lesbian" sexual practices - as in, sexual practices linked to the island of Lesbos-that were performed by women with other women. On the tribade in early modernity, see in particular Katherine Park, "The Rediscovery of the Clitoris: French Medicine and the Tribade, 1570-1620," in The Body in Parts: Fantasies of Corporality in Early Modern Europe, ed. David Hillman and Carla Mazzio (New York: Routledge, 1997), 171-93, and Valerie Traub, The Renaissance of Lesbianism in Early Modern England (Cambridge: Cambridge University Press, 2002), 188-228. For a critique of Park and Traub that emphasizes the circulation of knowledge about the clitoris and the presence of tribade-like women in material that was available during the Middle Ages, see Karma Lochrie, Heterosyncrasies: Female Sexuality When Normal Wasn't (Minneapolis: University of Minnesota Press, 2005), 71-89. For a survey of ancient references to tribades and an overview of the preceding scholarship on them, see Sandra Boehringer, L'Homosexualité féminine dans l'antiquité grecque et romaine (Paris: Les Belles Lettres, 2007), 146-49; 261-314. Boehringer contests the widely disseminated notion that in classical antiquity tribades were sometimes thought to penetrate women either with their enlarged clitoris or with a dildo. 
generally for a cautious Galenism."2 Concerned mostly with reproduction, these debates, of course, rarely included accounts of sex between women leading to female ejaculation. It is thus not the mention of sperm per se that is surprising, but instead its appearance as a sign of lesbian pleasure, particularly since sex between women was often represented, at least in literary texts, as impossible or necessarily unsatisfactory. ${ }^{3}$ At this point, I should perhaps clarify that I do not presume that there is any correlation between what may have been the sexual practices of historical women having sex with other women and the accounts of them that we find circulating in male-authored texts.

My discussion of Juvenal commentaries consists of two parts, the first focusing on the pre-print manuscript tradition and the second examining fifteenth-century print commentaries. I will also have occasion to consider the first Martial commentary that appeared in print. Before considering these commentaries, however, I will introduce the Juvenal passages that sparked many of the speculations on sex between women that are my primary concern in these pages. I use the Latin found in the 2004 Loeb edition of Juvenal and Susanna Braund's accompanying translation. ${ }^{4}$

\section{Juvenal on sex between women in Satire 6}

Very little is known about the historical Juvenal. His satires seem to have been written in the second and third decades of the second century CE. Today he is best known for the angry persona intoning against the decadence of contemporary life found in his first six satires, a figure he probably constructed by combining elements from the writings of his predecessors Persius, Horace, and Lucilius. As Braund notes, his later satires are more ironic and ultimately cynical (20). The first five satires are concerned with public life and address

2. Danielle Jacquart and Claude Thomasset, Sexuality and Medicine in the Middle Ages (Princeton, NJ: Princeton University Press, 1988), 70. See also Thomas Laqueur, Making Sex: Body and Gender from the Greeks to Freud (Cambridge, MA: Harvard University Press, 1990), 5-7.

3. For particularly sophisticated explorations of this commonplace, see Mary-Michelle Decoste, Hopeless Love: Boiardo, Ariosto, and Narratives of Queer Female Desire (Toronto: University of Toronto Press, 2009) and Traub, 276-325. There are examples of medical texts advising midwives to stimulate women to orgasm as a treatment for certain maladies (Traub, 84; Lochrie, 76-77).

4. Juvenal and Persius, trans. Susanna Morton Braund (Cambridge, MA: Harvard University Press, 2004). Translations from the commentaries are mine. 
patron-client relations, disappointment, and hypocrisy. The Sixth Satire, which includes the passages that concern us here, is the longest of them all and consists of a sustained diatribe seeking to dissuade its addressee Postumus from marriage. After explaining that Roman women of an earlier, less luxurious time were far more virtuous, the misogynous narrator observes that wealth has led to contemporary, early-second-century women's corrupt and decadent lifestyle. He then undertakes a sustained indictment of their sexual misbehaviour that can be divided into three parts. In the first of these, which I will not address at length, Juvenal describes a Venus ebria-either a "drunken Venus" or sex while intoxicated (6.300) -incapable of distinguishing between groin and head. This lack of discernment was widely taken to be a reference to oral sex, at times specifically including lesbian cunnilingus. ${ }^{5}$ In the second part, Juvenal's narrator invites the satire's nominal addressee - and presumably its readers - to marvel at the nocturnal adventures of a pair of female lovers before mentioning what the husband of one of the women finds the morning after. Commentaries on this passage will be the primary concern of the analyses below. It reads as follows:

Go on, ask yourself why Tullia sneers as she sniffs the air, and what notorious Maura's "foster-sister" says to her when Maura passes the ancient altar of Chastity. It's here that they halt their litters at night, it's here that they piss and fill the goddess's image with their powerful streams, and take it in turns to ride one another with no man present. Then off home they go. When the daylight has returned, you tread in your wife's urine on your way to call on important friends.

i nunc et dubita qua sorbeat aera sanna

Tullia, quid dicat notæ collactea Mauræ,

Maura Pudicitiæ veterem cum præterit aram, noctibus hic ponunt lecticas, micturiunt hic effigiemque deae longis siphonibus implent inque uices equitant ac nullo teste moventur. Inde domus abeunt: tu calcas luce reversa coniugis urinam magnos visurus amicos. (6.306-313)

5. On references to lesbian cunnilingus, see Marc Schachter, "Lesbian Philology in Humanist Juvenal and Martial Commentaries," in Ancient Rome and the Construction of Modern Homosexual Identities, ed. Jennifer Ingleheart (Oxford: Oxford University Press, 2015), 39-55. 
Juvenal's narrator describes Tullia and Maura-apparently two high-born Roman matrons-engaging in sacrilegious behaviour at the altar of the Goddess of Chastity, but what exactly they do isn't entirely clear in the Latin. Take for example the word micturiunt, translated by Braund as "they piss." While this may be merely a reference to a non-sexual form of defilement-the women literally urinate on or near the statue-in Juvenal's time, words for "urination" could be used to describe the emission of semen by men, and the word urina itself could be used both for male ejaculate and for female sexual secretions. ${ }^{6}$ Pointing out that micturiunt is actually a desiderative verb-that is, it expresses the desire to urinate or possibly to ejaculate-Yvan Nadeau argues that it means "that [the women] are seized with sexual excitement" (183).

Next, what exactly is it that the women do to the statue of the Goddess of Female Chastity? The verse in question, "effigiemque deae longis siphonibus implent," can be translated literally as "they fill the effigy of the goddess with their long siphons," but that doesn't exactly clarify matters. Taking siphonibus to be a reference to urine because of the preceding verb micturiunt, Braund translated the word as "streams" rather than "siphons." Nadeau, on the other hand, contends that they should be understood to be dildos (183). As for implent (they fill), the verb could be used for insemination in animal husbandry. ${ }^{8}$ Certainly, some sort of crude erotic meaning is available. Medieval and humanist commentators puzzled over the words implent and siphonibus but did not identify any explicit sexual signification for them. ${ }^{9}$ Their remarks, which were complicated by a textual variant addressed below, became heavily annotated with classical references, none of which, however, now seem particularly helpful in explicating the text.

The phrase "inque uices equitant" ("and they take it in turns to ride one another"), on the other hand, was-and still is-understood to be a reference to sex between women. In Latin, riding was frequently used as a metaphor

6. J. N. Adams, The Latin Sexual Vocabulary (Baltimore: Johns Hopkins University Press, 1991), s.vv. mingo, uesica, urina.

7. Yvan Nadeau, A Commentary on the Sixth Satire of Juvenal (Brussels: Editions Latomus, 2011). See also the remarks in Juvenal, Giovenale contro le donne (Satira VI), trans. with commentary by Franco Bellandi (Venice: Marsilio Editore, 1995), 147.

8. Adams, s.v. implo.

9. Or so it seems to me, but perhaps other scholars will understand things differently. I should emphasize that the commentaries themselves are not always self-evident. 
for sex. ${ }^{10}$ Glosses on it also underwent a transformation as humanists became aware of additional "information" about lesbian sexual practices in texts transmitted from antiquity. Documenting this transformation is one of the primary goals of the current essay. Finally, the passage about the husband walking in his wife's urine receives some remarkable glosses in the humanist interpretive tradition, most spectacularly by Domizio Calderino (1447-78). The last commentary printed in the fifteenth century, that of Josse Bade (1462-1535?), explicitly rehearses some of its predecessors' opinions. He singles out Calderino's gloss, which he both praises and contests. This, as well as its convenient 1498 publication date, makes it a fitting end point for my deliberations.

In the third scene of sexual depravity in Juvenal's triptych of moral outrage, the satire's narrator describes the rites of the Good Goddess during which women work themselves into an erotic frenzy. Although I will not address commentaries on this scene at length, I do address a couple of the glosses on it. Moreover, it is clear that some interpretations of Maura and Tullia at the altar of Female Chastity were influenced by the ensuing discussion of the rites of the Good Goddess and vice versa. Finally, two of the verses from this section will have a particularly important role to play in the dissemination of Juvenal's discussions of women who have sex with women. For all these reasons, I include the following lines as context for what follows:

Everyone knows the secret rites of the Good Goddess, when the pipe excites the loins and, crazed by horn and wine alike, the maenads of Priapus are carried away, whirling their hair and howling. How their minds are all on fire to get laid then, how they squeal to the dance of their desire, how abundant a torrent of undiluted lust runs over their dripping thighs! Saufeia takes off her garland and issues a challenge to the brothelkeepers' slave girls. She wins the prize for swinging her arse, then she in turn worships Medullina's undulating surges.

Nota Bonae secreta Deae, cum tibia lumbos

incitat et cornu pariter vinoque feruntur attonitate crinemque rotant ululantque Priapi

Maenades. O quantus tunc illis mentibus ardor 
concubitus, quae vox saltante libidine, quantus

ille meri Veneris per crura mantentia torrens!

Lenonum ancillas posita Saufeia corona

provocat et tollit pendentis praemia coxae,

ipse Medullinae fluctum crisantis adorat [...] (6.314-22)

Despite this racy opening, the scene goes on to suggest that women are incapable of achieving sexual satisfaction on their own. Their sexual exploits-real, Juvenal tells us, and not simulated-are so arousing that they could excite even Priam and Nestor, paradigmatic examples of decrepit and presumably impotent men (6.325-26; see Braund's note 63). Nonetheless, the women ultimately howl for a man to be let in to satisfy them. In this precursor to the pornographic leitmotif in which lesbian sex serves as the titillating foreplay before the main event with a man who can actually finish the job, the women even prove willing to accept the ministrations of a young donkey (asello, 6.334) if no man can be found.

Juvenal's description of the "torrent of undiluted lust"-Braund's translation of "meri Veneris [...] torrens"-running over the dripping thighs of women celebrating the rites of the Good Goddess would certainly seem to take the liquid in question to be a sexual secretion. A more literal translation of the Latin found in Braund's edition would be "torrent of Venereal wine," but this was not in fact what medieval and early modern readers encountered. Braund has emended the text here; where she has Veneris (venereal, or of Venus), the manuscript and early print traditions offer veteris (old). Nonetheless, the less appetizing "torrents of old wine" were considered to be the product of sexual excitement by some of the commentators addressed below. Saufeia and Medullina-high-born Roman matrons like Tullia and Maura mentioned above-also received a great deal of attention. As we shall see, they become part of a set of humanist commonplaces about sex between women assembled in the closing decades of the fifteenth-century that would have a long and influential career.

\section{The manuscript commentary tradition}

The pre-print commentary tradition is far too extensive to be considered exhaustively here. ${ }^{11}$ Instead, I address three important stages in the development

11. For an overview of the Juvenal commentary tradition, see Eva M. Sanford, "Juvenalis, Decimus Junius," in Catalogus Translationum et Commentariorum: Medieaeval and Renaissance Latin Translations 
of the tradition. I begin with the earliest extant commentary, much of which dates to the fourth century, less than three hundred years after the composition of Juvenal's Satires. Known as the scholia vetustiora, it has been meticulously edited in a modern edition. ${ }^{12}$ Next, I consider an extremely influential commentary composed in the tenth century that circulated widely under the name "Cornutus" from the twelfth century to the fifteenth. My transcriptions are from a fifteenth-century manuscript of the commentary held at the Biblioteca Medicea Laurenziana in Florence under the collocation Plut. 52.04. Finally, I turn to a fourteenth-century commentary composed at the cusp of the Renaissance. It exists in a single manuscript copy that is also housed at the Laurenziana under the collocation Plut. 34.36.

The scholia vetustiora recognized the sexual content of Juvenal's description of Maura and Tullia but did not explicitly remark upon its same-sex nature. We are told in a gloss to line 308 ("what notorious Maura's 'foster-sister' says to her") that Juvenal here explains "how Maura commits adultery."13 This observation may have been inspired by Martial's Epigram 1.90 about a woman named Bassa who seems chaste until it is discovered that she was having sex with her female visitors, which leads to the poem's conclusion in a "Theban riddle": "where no man is, there is adultery." ${ }^{14}$ The other glosses to the passage recounting Maura and Tullia's exploits do not include even a potential allusion to specifically female same-sex desire although their exploits are taken to include sexual activity. Juvenal's line about the women urinating receives the following remark: "At [the statue of] Female Chastity they lie together and urinate."15 The verb I have translated as "they lie together," concumbunt, was effectively a generic term for intercourse. Given that the reference to urination follows immediately after the evocation of sex, it should perhaps be taken as a reference to sexual secretions or sperm. Interestingly, the less equivocal reference to sex in the passage-("they take it in turns to ride one another") - receives no

and Commentaries, vol. 1 (Washington, DC: Catholic University of America Press, 1960). While my remarks in this essay are based on a substantial sampling of the extant manuscript tradition, it is possible that further research will necessitate some refinement.

12. Paul Wessner, Scholia in Juvenalem Vetustoria (Stutgard: Teubner, 1931).

13. "quomodo facit Maura adulterium" (93).

14. "hic ubi vir non est, ut sit adulterium," Martial, Epigrams, trans. D. R. Shackleton Bailey, Vol. 1 (Cambridge, MA: Harvard University Press, 1993) 108-09.

15. "apud Pudicitiam concumbunt et urinam faciunt” (93). 
direct comment, although perhaps concumbunt also refers to this expression. ${ }^{16}$ Glossing "longis siphonibus," the scholia also explain that the women fill the statue of the Goddess of Female Chastity "with jets of urine" and, maintaining the direct address to an imagined husband found in Juvenal, that "when you go forth in the morning, you tread in your wife's urine." 17 Although these explanations potentially retain some of the same ambiguity found in the original-are we to take urination and urine as urination and urine or as expressions meaning ejaculation and semen?- there is no direct reference to this possibility in a text that presumably seeks to clarify rather than obfuscate the work it annotates.

More influential, at least for the medieval period, is the commentary ascribed to Cornutus. Like the scholia vetustiora-but without being directly influenced by it - the Cornutus commentary recognized the sexual nature of the description of Maura and Tullia but did not explicitly address the fact that they were both women. Juvenal's "they take it in turns to ride one another" was interpreted to mean "they mount each other by turns and give and get back" (fol. 62v; "invicem se ascendunt et ferunt et referuntur"). Just as the scholia vetustiora used the verb concumbunt to refer to sexual activity, here too a generic euphemism is employed: ascendunt more literally means "they climb" or "they ascend." Its appearance here with the reflexive pronoun se-absent from the Juvenal line being glossed-makes the sense clear by avoiding the implication that Maura and Tullia mount the statue rather than each other. ${ }^{18}$ Juvenal's "in vices" (in turns) may have suggested to the commentator the use of both the active and the passive forms of the verb fero-which I have not entirely satisfactorily translated as "give and get back" - to describe the women's reciprocal sexual activities. If the Cornutus commentary betrays an awareness that the sex being described is between two women, it would lie in this alternation between active and passive. Such references to a kind of sexual versatility are worthy of note given the tendency in accounts of premodern sex to emphasize the centrality of a rigid dichotomy between active and passive roles in sexual expression. ${ }^{19}$ Whereas the roles in sex between men and women and between

16. “in vices equitant” (39).

17. "iactationibus lotii[s]" (39); "tu enim cum mane processeris, lotium calcas uxoris tuae" (94).

18. Nadeau actually argues precisely that the women mount the statue and not each other (183). There is no reflexive pronoun in the corresponding Juvenal passage.

19. This point is emphasized for example in Craig Williams, Roman Sexuality: Ideologies of Masculinity in Classical Antiquity (Oxford: Oxford University Press, 1999). For the argument that Juvenal's 
men and boys were generally assumed to be fixed, in Cornutus's description of Juvenal's account of sex between women, roles seem to be reversible. This is particularly interesting because some Roman accounts of the tribade emphasized that she took the active role in her encounters with other women (and indeed sometimes with other men). ${ }^{20}$

Another vague circumlocution appears in the comments to the Latin word siphonibus, which (as noted above) Braund translates as "streams" and Nadeau argues should be taken as dildos. "Cornutus" offers a third possibility:

Shells or tubes are here called "siphons," that is, the great vessels with which these women drank. Juvenal says not only that they did not venerate Female Chastity, but even that they did some sort of shameful deed in her temple and they hung the shells or tubes from the statue of the goddess.

Siphones dicuntur conchae idest magna vasa cum quibus biberant ipsae feminae, vel tubae. non solum, inquit, non venerantur Pudicitiam, sed etiam quaeque turpia agunt in templo eius et conchas vel tuba ad eius suspendunt simulacrum. (fols. 64v-65r)

"Cornutus" has here carefully avoided specifying precisely what it is that Maura and Tullia do in the temple of Female Chastity, referring instead to "quaeque turpia." This is all the more intriguing given the earlier observation that the two women urinate and lie together in the temple. Does "some sort of shameful deed" refer to the non-specified mechanics of their intercourse-to their urinating in the "shells or tubes" that they hang from the statue-or are they here imagined to be doing something else?

Next, we come to the fourteenth-century manuscript. It is comprised of a copy of Juvenal's Satires with a running marginal commentary as well as interlinear glosses in the same hand. Its annotations on sexual details are far more precise than those found in the earlier commentaries that I have considered, and they reflect both a Christian perspective and some familiarity with discussions on sex between women from classical antiquity. I will begin my consideration

representations of sex between women do not follow the hierarchical model, see Boehringer, 328-30.

20. Certainly, Martial's Epigram 1.90 mentioned above, in which women are said to "committere cunnos" (join two cunts), does not lend itself to the active-passive model. Epigram 7.67, on the other hand, presents a tribade with aspirations to virility who takes the more "male" role with girls and boys. 
of this manuscript with the least significant detail. Because of a textual variant that will also have an impact on some of the print commentaries to which I will turn shortly, rather than filling the statue of Female Chastity with long siphonibus, in Plut. 34.36 they do so with long symphonibus, which is glossed as follows: "with the sound that women make when they urinate." ${ }^{21}$ Above "inque vices equitant" ("they take it in turns to ride"), we find "they take turns undulating wantonly." 22 The Latin verb criso is a technical term for the movement made by a woman during sex. The corresponding term for men is ceveo. In The Latin Sexual Vocabulary, Adams points out that both terms are used for the "passive" partner during sex (136). ${ }^{23}$ This perhaps explains the passive verb crissantur found in the manuscript commentary. A participial form of the same verb is found in line 322 of Juvenal's Sixth Satire: "she worships the pleasure of undulating Medullina" ("ipsa Medullinae fructum crisantis adorat"). (Note that this line includes another textual variant; where modern editions have fluctum, translated by Braund as "surges," Plut. 34.36 offers fructum, or "pleasure." Yet other manuscripts have frictum, or "rubbing.") The commentator may have found the verb criso in this adjacent section of the satire and used it to explain the earlier passage. I, in turn, have borrowed Braund's felicitous translation of criso, rendering it with forms of the English word "undulate."

The interlinear gloss on the second half of the line about the women riding is potentially more significant because it may include vocabulary drawn from outside of the Satires to explain the discussion of sex between women in Juvenal's text. For moventur-which Braund does not specifically translate but which certainly refers to some kind of erotic movement-we find the following note: "They rub [or: are rubbed] one against the other" ("Fricantur una cum alia"). The term fricantur (here perhaps in the passive because moventur is in the passive?) is particularly significant because the verb frico, "to rub," is the standard Latin translation offered for the Greek verb tribô, which as noted above is the source for the word "tribades." A related word appears in an interlinear gloss just above the variant fructum mentioned above: "that is, rubbing" ("idest fricationem"). These two words-fricantur and fricationem-suggest that the author of the commentary may have been aware of a broader classical

21. "sonitibus quod faciunt quando mulieres mingunt" (fol. 25r).

22. "crissantur ad invicem luxuriando" (fol. 25r).

23. See also Williams, 178. 
discourse around women who have sex with women. The most likely source would have been Martial's Epigram 7.67, in which the word "tribade" appears. As we shall see below, what is here only potentially a reference to Martial becomes an explicit link in the following century.

A marginal comment explicating Juvenal's account of the husband who walks in his wife's urine also anticipates subsequent commentaries. Here, we find 'And for 'urine' understand here 'sperm' which during the previous night by the light of the moon itself had been emitted from the women's mutual undulations." ${ }^{24}$ The commentator has assumed that the husband has walked in the "sperm" (sperma) emitted by his wife earlier in the temple of the Goddess of Female Chastity. The word sperma may reflect the increased availability of medical and gynecological texts from the Galenic tradition as more Arabic and Greek works were translated into Latin during the thirteenth and fourteenth centuries. ${ }^{25}$ Finally, and most unusually, this commentary uses the term sodomy to explicate the line containing the phrase "the brothel keeper's slave girls" (6.320): "Placed here is the greatest vice of the Romans. Evidently, the practice of sodomy reigned in them." ${ }^{26}$ No other manuscript commentary I have come across uses the category of sodomy to characterize the lesbian sections of the Sixth Satire. By contrast, an earlier reference to pederasty was routinely identified as an example of the sodomitical vice. ${ }^{27}$ What the use of the term sodomy to describe sexual relations between women might say about the context within which Plut. 34.36 was produced is an avenue of inquiry that would be worth pursuing. The manuscript is contemporary with the dissemination of legal

24. "et per urinam intellige ad huc sperma quod in nocte tunc proxima praeterita ad lumen lune ipse mulieres emisera in crissatione una cum altera" (fol. 25r).

25. For an overview of this linguistic transmission, see Jacquart and Thomasset, 48-70.

26. "hic posita est maxima vitia romanarum. Scilicet sodomiticum exercitium regnare in ipsis" (fol. 25r).

27. Near the opening of the Sixth Satire, the narrator suggests to Posthumus that it is better to sleep with a pusio (6.34; "boy," or-in Braund's translation- "boyfriend") than with women because a boy is far more likely to be docile. Representative medieval responses to this passage include Bibliothèque nationale de France ms. Lat. 16698, a thirteenth-century Commentum Juvenalis, where we find "pusio est cathamitus et hic tangit sodomitico vitio" (fol. 33v; "the boy is a catamite and Juvenal here touches on the sodomitical vice") and BnF ms. Lat. 8073, a Juvenal commentary dated to 1307, which remarks, "Malum exemplum de vitio sodomitico" (fol. 30r; "a negative exemplum of the sodomitical vice"). 
justifications for the punishment of women for having sex with other women. ${ }^{28}$ Intriguingly, the three elements I have identified in Plut 34.36 that do not figure in the Cornutus commentary-the identification of urine with sperm, the use of the verb frico to describe sex acts between women, an invocation of sodomy to refer to such acts-would all figure in at least one of the fifteenth-century print commentaries.

\section{The fifteenth-century print commentaries}

The fifteenth-century print commentaries on Juvenal reflected the increased availability of and interest in the classical texts characteristic of humanism as well as fierce competition among humanists. Both interest and competition can be found in the gloss on the phrase "longis symphonibus implent" found in the first print commentary on the Satires, the 1474 Paradoxa in Juvenalem by Angelo Sabino (fl. 1460s-1470s): "because urinating harmoniously and they are not pipes made of lead as some dream."29 Among these dreamers was Domizio Calderino, with whom Sabinus had a great rivalry, for he identified siphonibus precisely as "pipes made of lead." ${ }^{30}$ Note that this dispute in part results from a textual variant-according to Sabino, the word whose meaning is under dispute should be symphonibus, or "harmoniously," and not siphonibus, which Calderino took to be lead pipes, Braund translated as "streams," and Nadeau argued were dildos. Calderino responded in kind by zeroing in on a detail found in Sabino's Paradoxa concerning the word implent ("they fill"). Sabino had written, "At this point, Juvenal looks back at what Nero did according to Suetonius when he ordered that urine be shot into the statue of the Syrian

28. Decoste, 16-17. See also Joan Cadden, Meanings of Sex Difference in the Middle Ages: Medicine, Science, and Culture (Cambridge / New York: Cambridge University Press, 1993), 224 and Louis Crompton, “The Myth of Lesbian Impunity: Capital Laws from 1270 to 1790," Journal of Homosexuality 6.1-2 (Fall/Winter 1980-81): 11-25.

29. "quia mingendo consonante nec sunt cannae plumbeae ut somniant quidam" (sig. h5r). Angelo Sabinus, Paradoxa in Iuvenalem (Rome: Georgius Sachsels and Bartholomaeus Golsch, 1474).

30. "cannae plumbeae" (sig. elv). Domizio Calderino, Commentarii in Iuuvenalem. Cum Defensione Commentariorum Martialis \& Recriminatione Aduersus Brotheum Grammaticum (Venice: Jacques le Rouge, 1475). 
Goddess who according to Strabo was called Atargatas."31 In a classic example of humanist snark, Calderino responded as follows in his gloss to implent:

I do not think that the urine was shot into the mouth of the Goddess of Female Chastity by the women but that the women urinated next to the altar where later they copulate in turns. The poet is alluding to an old custom, namely that when the statue of a god was defiled, it was drenched in urine, as Suetonius teaches in his Life of Nero: cleverly, he says that the women do this mocking the goddess.

non intelligo locium in os pudicitiae deae iactum fuisse a mulieribus sed mulieres iuxta aram minxisse. ut postea vicissim coirent: Poeta autem alludens ad veterem morem: quod cum simulacrum dei contaminabatur perfundebatur urina ut Tranquillus in Nerone docet: cavillando ait mulieres id egisse deam contemnentes. (sig. e1v)

Although Sabinus may not have said specifically that Maura and Tullia urinated in the statue of the Goddess, he did imply as much through his learned paraphrase of Suetonius. Calderino finds this idea preposterous and mocks his predecessor's opinion by trying to imagine how one could do so-right into the mouth of the statue? - before offering his own opinion, namely that the women urinated not in but next to the effigy of Female Chastity. Having differentiated his opinion from that of Sabino, he goes on to mention the Suetonius reference, which he casts as a playful allusion.

Sabino's remarks about sex between women also responded to an increased awareness of classical antiquity. In the Paradoxa, Juvenal's "they take it in turns to ride" receives the following gloss: "Some say that Lesbian women invented this practice. Hence Sappho is called a tribade and Philaenis is called a tribade in Martial." ${ }^{2}$ This gloss is filled with details not seen in the manuscript tradition considered above: women from Lesbos invented a female same-sex

31. "Ad illud respicit quod Nero fecit teste Suetonio dum urinam proiici iussit in statuam deae Syriae quae teste Strabone atargata dicta fuit" (sig. 5hr). Sabinus here refers to Suetonius's Life of Nero 56 and to Strabo's Geography 16.1.30.

32. "quidam Lesbydas hunc usum invenisse perhibent hinc tribas sappho dicta \& philenis tribas apud Martialem" (sig. 5hr). 
act (presumably the mutual riding), Sappho was said to be a tribade, and so was Philaenis in Martial's Epigrams. Where does all this information come from?

The Martial reference is easy. Sabinus is thinking of Epigram 6.67, a poem about the sexual exploits and virile pretentions of a tribade named Philaenis. He actually cites this very epigram slightly earlier in the commentary (sigs. $\mathrm{h} 4 \mathrm{v}-\mathrm{h} 5 \mathrm{r}$ ). As for the notion that Sappho was said to be a tribade, it can be found in the first print Martial commentary, written by none other than Sabino's rival Domizio Calderino and which, like Sabino's Paradoxa in Juvenalem, was published in 1474. In his Martial commentary, Calderino writes the following about Epigram 6.67:

Women in turn abused in masculine coupling. Juvenal condemns them in his satirical poem: "having put aside her garland, Lauseia challenges the maids of the procurers" and a little further on "She herself worships the rubbing of Medullina's undulating thighs." Tribades can also be called with the Latin word "fricatrices." Tribô means "to rub" in Greek. No author used the word but Martial, except Porphyrion about the following phrase in Horace: “And masculine Sappho." He remarks that Sappho was said to be masculine, either because she made works of poetry-that is, of men and of the masculine-or because she was a tribade.

Mulieres virili concubitu vicissim abutebantur. Has damnat Iuvenalis carmine satyrico: "Lenonum ancillas posita Lauseia corona provocat" et paulo post "Ipsa Medullinæ frictum crissantis adorat." Latino verbo "fricatrices" possunt appellari tribades. $\tau \rho i \beta \omega$ significat "frico" Græco. Usus est Martialis præter hunc nullus auctor Porphirione excepto, qui in verba illa Horatii: "Et mascula Sappho." Sappho, inquit, dicta esse mascula, vel quod dedit operam poeticæ (quod est viri et maris) vel quod tribas fuit. (sig. $02 \mathrm{v})^{33}$

Presumably, Calderino suggests that "women in turn abused" because Martial proclaims in the first line of the epigram that Philaenis sodomizes boys ("paedicat") before going on to discuss her sexual exploits with girls. Calderino next cites two lines from the Juvenal passage about sex between women that 
elicited the glosses at the centre of this essay. He then makes an explicit link between the word "tribade," the Latin verb frico, and the Greek verb tribô through his references to Martial and Porphyrion. The Porphyrion in question is the second or third century grammarian Porphyrion Pomponius, who wrote a commentary on Horace in which he opined that Horace used the phrase "masculine Sappho" (mascula Sappho) in his Epistles (at 1.19.28) either because Sappho had engaged in the masculine pursuit of writing or because she was a tribade.

Whether Sabinus influenced Calderino or Calderino influenced Sabinus is difficult to say. Because they both lectured at the University of Rome, the ideas found in their commentaries were in circulation before they were published. (This is why I can suggest that a work printed in 1474 may be responding to ideas found in another that would not appear until 1475.) Moreover, the two men moved in overlapping intellectual circles and were part of the sustained engagement with Martial, Juvenal, and other classical authors that was carried on through various public and private venues. Yet in a sense this is beside the point. In their commentaries, we are witness to the incipient establishment of a set of humanist commonplaces about sex between women, a project that seems to have begun in earnest with the editing in print of the classical authors referenced and with the preparation of lectures and then print commentaries on them. Before or around 1470, the glosses on the "lesbian" sections of Juvenal's Sixth Satire in the manuscripts I have consulted do not include explicit references to Martial, to Sappho, or even to the word tribade and its Greek etymology. On the other hand, as we saw earlier, the appearance of the verb frico in the discussion of Juvenal's representation of sex between women in Plut. 34.36 does suggest that the author of that commentary may very well have had enough familiarity with Martial to draw some of the same connections we find more fully fleshed out in commentaries by Sabinus and Calderino.

One enigma however remains. While the suggestion that Sappho was a tribade can be explained by Porphyrion's commentary on Horace, what about Sabinus's claim that Lesbian women - as in, women from the Island of Lesbosinvented a female-female sexual practice? Where might it have come from? The answer to this question can be found in Domizio Calderino's gloss on "inque vice" in his 1475 Juvenal commentary: 
Lesbian women first instituted mutual rubbing, whence in Aristophanes lesbizein means to do this. Martial calls them tribades from the Greek tribô, which means "to rub." Such was Sappho, as she confesses and Porphyrion teaches.

Lesbiae mulieres mutuo fricari primo instituerunt, unde apud Aristophonem $\lambda \varepsilon \sigma \beta i \zeta \varepsilon v v$ id agere est. Martialis tribadas appellat a $\tau \rho i \beta \omega$, quod est frico. Qualis fuit Sapho, ut ipsa fatetur et Porphyrio docet. (sig. e1v)

Calderino's gloss here is a more developed version of what we saw in Sabino's commentary. Whereas Sabinus did not specify the precise act that the Lesbian women were said to have invented, here we are told that it is mutual rubbing. We are also told that Aristophanes used the verb lesbiazô, literally "to act like someone from Lesbos," as a synonym for tribô, or rubbing. Where, in turn, might this information have come from?

Calderino's potential sources for this idea make it clear that Aristophanes used the verb lesbizô and that the people of Lesbos were indeed said to have invented a sexual practice, but also that he was wrong about which practice they invented. In the Suidas, a tenth-century Byzantine dictionary and historical encyclopedia that Calderino is known to have consulted since he quotes from it in his commentary on Ovid's Heroides, we are told that the verb lesbizô means "To pollute the mouth. For the people of Lesbos used to be slandered for this shameful act." ${ }^{34}$ In other words, lesbizein means to perform oral sex, and perhaps more specifically, to fellate. The Suidas also indentifies Aristophanes as the witness for this term. The same information can be found in the Aristophanic scholia, a set of ancient glosses on the comedies that was not published until after Calderino's death, but which could have been available to him in manuscript.

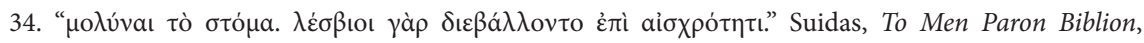
(Ioannes. Bissolus and Benedictus Mangius for Demetrius Chalcondylas, 1499), s.v. $\Lambda \varepsilon \sigma \beta i ́ \sigma a$. My translation. I should note that the word " $\lambda \dot{\varepsilon} \sigma \beta ı$ เ " (sic), which I have translated as "the people of Lesbos," is ambiguous. It could mean "Lesbian men," as in men from Lesbos, or it could mean "Lesbian People." The verb lesbizô was used of both men and women performing fellatio. On Calderino's use of the Suidas in his Ovid commentary and the implications of the discussion of Sappho there, see Harriette Andreadis, Sappho in Early Modern England: Female Same-Sex Literary Erotics, 1550-1714 (Chicago: University of Chicago Press, 2001), 28-30. 
Presumably, Calderino's error results from the strength of the link associating sex between women with rubbing.

Next we come to Calderino's gloss on the husband treading in his wife's sperm. Remember that the wife in question has spent the night with a female companion desecrating the statue of the Goddess of Female Chastity, possibly by urinating on it and definitely by engaging in some sort of sex act. Calderino writes:

That is, you want to get up in order to pay your respects to wealthy friends, but first you want to have sex with your wife. You find no sperm in her, however, for she exhausted her loins at night with other women. You therefore tread only in her urine and not in sperm.

Idest, cum vis surgere ad salutandos divites amicos, tu prius vis coire cum uxore. Sed nihil spermatis in ea reperis, nam exhausit lumbos nocturno tempore cum aliis mulieribus. Tu igitur tantum calcas eius urinam et non sperma. (sig. e1v)

Where the commentary found in Plut. 34.36 assumed that the husband walked in his wife's urine (understood as sperm) while in the temple of the Goddess of Female Chastity, Calderino proposes that her sexual activities at the altar so drained her that when her husband has sex with her he finds that she is incapable of producing any more sperm. As noted above, the Good Goddess scene with its all-female orgy ultimately preserves patriarchal pieties by implying that the women could not ultimately achieve satisfaction without a man. Calderino's account seems instead intentionally anxiogenic, particularly given the suggestion that the wife's activities will keep her from being able to conceive as well as contemporary concerns about the sexual voracity of women and men's inability to satisfy them.

The next Juvenal commentary was that of Giorgio Merula (1447-78). He completely ignores Calderino's gloss on the husband's morning encounter with his wife's urine (fol. 88r) and offers the most abbreviated discussion of the word "tribade" found in the post-Calderino print commentaries considered here 
(fol. 89r) ${ }^{35}$ Giorgio Valla (1447-1500) also ignores Calderino's gloss on urina. He does show a newfound interest in the textual tradition of Juvenal, however. For example, commenting on the word syphonibus he observes that "almost all the ancient manuscripts have 'with the harmonious sounds of urine' but in the corrected ones we find 'with siphons." ${ }^{36} \mathrm{He}$ agreed that the women taking turns riding (6.311) were having sex with each other and noted that "she who does this is usually called 'tribade," but rather than looking to Martial to adorn his remarks, in a bravura display of translatio homophobiae, he instead cited Plato's Laws (363c), Paul's Letter to the Romans (1:26), and Ambrose's Commentary on Romans on this passage in Paul's letter to condemn such comportment. ${ }^{37}$

Antonio Mancilla (1451?-1505), author of the next Juvenal commentary, does not directly engage with Calderino's gloss on the husband's morning encounter but he does implicitly refute it by remarking that "you tread in urine" refers to "what the woman had emitted, for Juvenal said 'they urinate here." 38 In other words, he shares the opinion expressed in Plut. 34.36 that the husband treads in his wife's secretions while in the temple of the Goddess of Female Chastity, although unlike the commentator in Plut. 34.36, he takes urine for urine and not sperm. Finally, whereas Valla had turned to religious texts to gloss references to sex between women, Mancilla returns to the tradition inaugurated by Sabino and Calderino, quoting Martial's Epigrams 1.90 and 7.67 in his discussion of the relevant passages in Juvenal.

It is only when we come to Josse Bade's commentary, the last printed in the fifteenth century, that we find an explicit engagement with Calderino's gloss on urina. His interpretation of the husband's encounter begins with his annotation to inde (6.312; "from which place"). Rather than specifying the place from which the women returned home, which inde would lead us to expect, he instead details the sexual activities that they left, activities which are said to have generated semen: "that is, from such mutual rubbings [...] or undulations,

35. Juvenal, Argumenta Satyrarum Juvenalis [...] Cum Quatuor Commentariis (Venice: Joannes de Cereto alias Tacuinus de Tridino, 1498). I have used this volume for the commentaries of Merula, Valla, and Mancilla. The fourth commentary is that of Calderino.

36. "symphonibus urinarum sonitibus quasi concentibus in antiquis tamen \& emendatis codicibus legitur syphonibus” (fol. 88r).

37. "Quae id facit tribas solet appellari” (fol. 88r).

38. "quam femina emiserat nam dixit micturiunt hic" (fols. $87 \mathrm{v}-88 \mathrm{r}$ ). 
through which they emitted semen." ${ }^{39}$ Bade thus understands micturiunt not to refer to urination but rather to (female) ejaculation. His gloss continues with an expansive paraphrase of Juvenal's text as well as observations about the interpretations proposed by Mancilla and Valla. He notes that Mancilla implied that the husband treads in the urine of his wife in the temple where she had earlier urinated, and that Valla proposes essentially the same thing. Then, he turns to Calderino's gloss, remarking that it is "far more subtle and suitable to the text" ("longe subtilior \& textui quadrans") before repeating Calderino's analysis word for word. He then offers his critique as well as his own interpretation of the passage:

The word calcas (you tread) however opposes this [=Calderino's interpretation] because it is certain that sex cannot be derived from any "treading." According to me, the meaning is "you desire to see," that is, at first light you get up to see and greet your great friends, who offer gifts. "you tread in your wife's urine": which drunk and burning with desire from her earlier undulations she left in front of your bed to which she returned from the temples.

Quibus obstat verbum calcas: quod a calcibus quibus coitus non sit nimirum deducitur. Unde mea sententia est: tu visurus: idest dum prima luce surgis ut visas et salutes magnos amicos, qui sportulam dant: calcas urinam coniugis: quam ebria \& prurigine ardens ex crissatione preterita dereliquit ante lectum tuum: ad quem se ex sacris recepit. (fol. 85r)

Bade here disagrees with Calderino on philological grounds: he asserts that the word calcas (you tread) cannot be taken as a euphemism for sexual intercourse, as it must for Calderino's interpretation to be convincing. Nonetheless, he appreciates Calderino's gloss apparently because it does not make the assumption - as Merula and Valla had - that the husband encounters his wife's urine in the temple of the Goddess of Female Chastity. Instead, Bade contends that the urine in which the husband treads is the result of his wife's continued sexual excitement. Thus, although he does not explicitly address the issue, he

39. "id est ex tali confrictione [...] seu crissatione per quam semen emiserunt" (fol. 88r). Juvenal, Juvenalis Familiare Commentum Cum Antonii Mancinelli Viri Eruditissimi Explanatione (Lyon: Bibliopola Stephano Baynardo, 1498). 
has also offered an ideological correction to Calderino's text in addition to the philological one. Whereas Calderino understood the wife to have come home so exhausted-as in, utterly sated-by her prior sexual activities with other women that she is incapable of producing more sperm, Bade contends that she returned from those activities effectively unsatisfied and still burning with desire, the trace of which is the "urine" she leaves by her husband's bed. ${ }^{40}$

\section{Conclusion}

In a recent article, Helmut Puff has called for a "lesbian philology" that would attend to neo-Latin sources as well as the vernacular ones that have received more attention. ${ }^{41}$ Certainly, prior scholarship has not entirely ignored neo-Latin material. In particular, legal documents and the classical antecedents for early modern medical texts have been studied at length. While the importance of some classical authors, in particular Ovid and Martial, has been considered by historians of lesbian sexuality, however, the neo-Latin commentaries on them largely remain an undiscovered country. An important exception is the work on Ovid commentaries undertaken by Harriette Andreadis and others. As I hope this essay has demonstrated, Juvenal and Martial commentaries are also worthy of our attention. In particular, we find in them the development of a set of humanist commonplaces about sex between women and the tribade that emerged in the 1470s. Some of these commonplaces may in turn have shaped the reception of classical authors by vernacular writers in the Renaissance.

What finally to make of Calderino's gloss about a woman so satiated by sex with other women that she cannot make any more sperm during intercourse with her husband? As we just saw, Bade was not entirely convinced by this argument and saw fit not only to critique it on philological grounds but also to propose another interpretation that would once again represent sex between women as exciting but not ultimately satisfying. It was however not his interpretation that would be most frequently reprinted in the ensuing

40. Bade's is the only fifteenth-century print commentary to refer to sex between women in terms of sodomy. In a gloss to the passage that mentions Lauseia's challenge to the slave girls (6.320-21), he writes that "provocat at certamen sodomiticae libidinis" (fol. 85v; "she challenges [them] to a contest of sodomitical desire").

41. Helmut Puff, “Towards a Philology of the Premodern Lesbian," in The Lesbian Premodern, ed. Noreen Griffney, Michelle Sauer, and Diane Watt (New York: Palgrave, 2011), 145-57. 
decades. That honour belonged to Calderino's commentary which circulated most widely until the early seventeenth century when other commentaries took its place. ${ }^{42}$ Glosses like the one on the husband's encounter with his wife's urine probably help explain why. Calderino's ingenious and sensational interpretations of the Satires stand out amid the dry and often censorious rhetoric of his contemporaries. Given its enormous popularity, we can be confident that many Renaissance authors capable of reading Latin and with an interest in classical antiquity had access to Calderino's commentary. Whether we can find evidence that it influenced the works of later authors, be they in Latin or in the vernacular, remains to be seen. But if we do not know what is in commentaries such as Calderino's, then we will not be able to consider them in their own right let alone attend to their broader potential role in the history of sexuality. ${ }^{43}$ 